\title{
$\mathrm{H}$ 감비탕(GB-001)이 폐경 전·후 비만 여성의 체중감량에 미치는 영향에 대한 후향적 연구
}

조홍석·서연호·김고운 · 조재흥 · 송미연

경희대학교 한의과대학 한방재활의학과교실

\section{The Retrospective Analysis of Effects of $H$ Gambitang (GB-001) on Weight Loss in Pre- and Post-Menopausal Obese Woman}

\author{
Hong Seok Cho, Yeonho Seo, Koh-Woon Kim, Jae-Heung Cho, Mi-Yeon Song \\ Department of Korean Rehabilitation Medicine, College of Korean Medicine, Kyung Hee University
}

Received: April 16, 2020

Revised: May 27, 2020

Accepted: June 9, 2020

Correspondence to: Mi-Yeon Song Department of Korean Rehabilitation Medicine, College of Korean Medicine, Kyung Hee University, 26,

Kyungheedaero, Dongdaemun-gu,

Seoul 02447, Korea

Tel: $+82-2-440-7575$

Fax: $+82-2-440-7287$

E-mail: mysong@khu.ac.kr

Copyright $\odot 2020$ by The Society of Korean Medicine for Obesity Research
Objectives: The purpose of this study is to verify the effects of H Gambitang (GB-001) on body composition and basal metabolic rate in pre- and post-menopausal obese woman retrospectively.

Methods: The study was conducted on 57 middle-aged obese women. They were divided into two groups; pre-menopausal obesity group (Pr-MOG; n=34) and post-menopausal obesity group (Po-MOG; amenorrhea was continued to 14 48 month, $n=23$ ) with no significant difference of age, height, body weight and body mass index. All subjects took herbal medicine 3 times a day, for 6 weeks during treatment period. The weight, height, body fat mass, skeletal muscle mass, and basal metabolic rate of all subjects were measured on first visit. The following measurements were repeated after 2 weeks (2nd), 4 weeks (3rd) and 6 weeks (4th) with Inbody 370 (Biospace) equipment to identify changes of body fat mass, skeletal muscle mass, and basal metabolic rate. Results are represented as mean and standard deviation.

Results: Po-MOG showed significantly lower decrease rate in weight reduction on 2 6 weeks while significantly higher decrease rate in skeletal muscle reduction on 4 6 weeks. There were no significant differences between two groups in body fat reduction rate and basal metabolic increasing rate.

Conclusions: H Gambitang (GB-001) can be used not only in Pr-MOG but in Po-MOG in weight loss although the effect can be lower in Po-MOG. To prevent skeletal muscle mass loss in Po-MOG, following study on adjusting dose and components of $H$ Gambitang $(G B-001)$ thought to be necessary.

Key Words: Menopause, Obesity, Herbal medicine
서론

중년 여성은 연령이 증가함에 따른 신체적, 생리적인 부정적 변화와 일상생활의 신체활동 부족으로 인해 비만 을 포함한 고혈압, 당뇨병, 고지혈증 등의 생활습관병 유 병률이 높은 것으로 보고되고 있다1). 더욱이 중년 여성은 45 55세 사이에 난소의 기능 저하에 따른 여성 호르몬 에 스트로겐(estrogen) 분비 감소로 폐경을 맞이함으로써2-4), 체지방과 복부지방의 증가, $8 \sim 10 \%$ 의 기초대사량 감소로 인해 보다 더 다양한 신체적 변화와 그에 따른 높은 비만 유병률을 나타내게 된다 ${ }^{5,6)}$. 이에 따라 여성 일생의 $35 \%$ 이상을 차지하는 폐경 후 삶의 질 개선 및 향상을 위해서 비만의 치료가 중년 여성의 건강관리를 위해 매우 중요하 게 강조되고 있다). 
일반적으로 중년 여성의 급변하는 신체적 변화와 그에 따른 비만을 개선 · 예방하여 건강을 증진하기 위한 방법 으로 운동요법, 식이 요법, 약물요법, 행동수정요법, 수술 요법 등이 권장되고 있다 ${ }^{8-11)}$. 또한 우리나라는 한방 병 의원에서 한약, 침치료, 침전기 자극요법 및 약침치료 등을 통해 전신 혹은 부분 비만치료도 많이 시행하고 있으며, 이 중 한약을 이용한 비만치료가 높은 빈도로 시행되고 있다 ${ }^{10-14)}$.

비만치료 한약은 식욕 억제, 에너지 대사율 증가, 지방조 직의 에너지 소비 증가(산소포화도를 높임)에 따른 체지방 분해 가속화, 운동수행능력 향상 등의 효능이 있으면-17), 많은 선행 연구를 통해 체중감량 및 비만치료 효과가 입 증되고 있다 ${ }^{18,19)}$. 비만치료 한약에 대한 연구는 연령20-22), 비만정도 ${ }^{13,23,24)}$, 기저질환 ${ }^{25-27)}$, 사상체질 ${ }^{14,28,29)}$ 등에 따라 다양하게 수행되었으나 그 동안의 연구들은 대부분 연령대 를 특정하지 않은 연구들이 많았다. 연령을 특정한 연구들 중에도 폐경 전 여성을 대상으로 한 연구익ㅇㅇㅘ 폐경 여성 을 대상으로 한 연구 ${ }^{32)}$ 는 있으나 동일한 한약을 복용했을 때 폐경 전·후 여성에서 어떤 효과가 있는지 비교한 연구 는 전무한 실정이다. 따라서 신체조성과 비만의 유형에 있 어 폐경 전 여성과 다른 분포를 보이는 것으로 알려진 폐 경 후 여성에서 비만치료의 효과가 어떻게 나타나는지에 대한 경향성을 살펴보는 것이 필요할 것으로 생각된다.

이와 같은 필요성에 의해 본 연구는 하늘체한의원 춘 천점에서 2015년 5월 6일부터 2019년 6월 30일까지 비만 치료 한약인 H 감비탕(이하 GB-001)을 복용한 환자 중 폐경 전·후 비만 여성을 대상으로 신체구성 및 안정시 대사율의 변화를 후향적으로 주기별 비교 - 분석하여 보 고하고자 한다.

\section{대상 및 방법}

\section{1. 연구 대상}

본 연구는 2015년 5월 6일부터 2019년 6월 30일까지 하늘체한의원 춘천점에서 비만치료를 받기 위해 내원한 환자 중 GB-001을 복용한 45 55세의 비만 여성 57명을 대상으로 하였다. 선정된 연구 대상자들은 폐경 전 비만 여성 $(n=34$, 무월경의 경험이 없는 여성)과 폐경 후 비만 여성 $(n=23$, 무월경이 $14 \sim 48$ 개월 이상 지속된 자연적 폐 경)으로 분류하였다.
(1) 남성, (2) 44세 이하와 56세 이상의 여성, (3) 중증 질환자, (4) 흡연자, (5) 약물 복용자, (6) 의학적 수술 경 험자, (7) 규칙적인 운동참여자, (8) GB-001의 불규칙적인 복용자(3회/1일), (9) GB-001 외 다른 전신 혹은 부분 비 만치료 시술 병행자, (10) 치료 개시 처방된 GB-001을 체 질, 변증 및 병력 등에 의해 변경 복용한 자, (11) 비만치료 기간 중 이상 반응자 및 부작용자, (12) 재내원 지연자 및 측정 자료 확인 불가자는 연구 대상에서 제외하였다.

본 연구는 환자의 개인식별정보를 기록하지 않은 후향 적 연구이며, 기록된 자료는 연구목적으로만 활용된다는 것에 대하여 연구대상자들의 동의를 받고 진행하였다.

\section{2. 연구 방법}

\section{1) 한약 비만치료 과정}

분석 자료 선정 및 제외 기준을 확인하기 위한 모든 환 자의 연령, 성별, 성명, 폐경 유무, 일상생활의 신체활동 수 준, 흡연, 약물복용, 질환 및 수술 경험 등을 포함한 환자의 신상정보, 생활습관 및 과거력은 치료 개시 전에 작성된 문진-설문지를 통하여 확인하였으며, 치료 개시 이후 신상 정보, 생활습관, 과거력의 변경으로 연구 분석 제외 기준에 해당되는 연구 대상자는 치료 2주 후, 4 주 후, 6 주 후 총 3 회에 걸친 상담 자료 리뷰를 통해 확인하여 분석에서 제 외하였다.

분석에 포함된 모든 환자들은 하늘체한의원 춘천점에 서 비만치료를 위해 처방되는 한약인 GB-001을 비만치료 개시에서 치료 6 주가 완료될 때까지 1 일 3 회, 식전 30 분 에 동일하게 복용하였다(Table 1). 또한 GB-001의 복용 방 법을 포함하는 단식과 절식이 없는 자가-식이요법과 일상 생활 신체활동 등과 같은 생활관리 교육이 치료 개시, 치

Table 1. Composition and Amount of H Gambitang (GB-001)

\begin{tabular}{llc}
\hline Herb & \multicolumn{1}{c}{ Scientific name } & Amount $(\mathrm{g})$ \\
\hline Mahuang & Ephedra herba & 10 \\
Yiyiren & Coicis semen & 10 \\
Danggui & Angelicae Gigantis Radix & 10 \\
Shudihuang & Rehmanniae Radix Preparata & 10 \\
Longyanrou & Longanae Arillus & 10 \\
Shanyao & Dioscoreae Rhizoma & 10 \\
Fuling & Poria & 10 \\
Zexie & Alismatis Rhizoma & 10 \\
\hline
\end{tabular}

Composition of $H$ Gambitang for 1 day. 
료 2주 후, 4주 후 총 3 회 제공되었으며, 모든 연구 대상 자의 신체계측 및 신체구성 검사는 치료 개시, 치료 2 주 후, 4 주 후, 6 주 후 총 4 회에 걸쳐 수행되어 전산화 기록하 였다. 이후 모든 연구 대상자의 전산화되어 기록된 측정 자료는 후향적으로 수집, 통계적으로 분석-처리하였다.

\section{2) 측정 방법 및 도구}

(1) 신체계측

신장 자동측정장치(BSM330; Inbody, Seoul, Korea)를 이용하여 신장을 측정하였으며, 모든 연구 대상자들은 측 정 시 가벼운 운동복 차림에 신발과 양말을 벗은 상태에 서 측정하였다.

\section{(2) 신체구성}

생체전기임피던스법(bioelectrical impidance analysis)을 이용하는 체성분검사기(Inbody 370; Biospace Inc., Seoul, Korea)로 모든 연구 대상자들의 체중, 체지방률, 골격근량 및 안정시대사율을 측정하였다.

체성분검사법은 고주파수의 전류를 전도시켜서 지방 조직과 비지방조직의 전기저항 차이를 이용하는 장비로 써 치료 개시, 치료 2주 후, 4 주 후, 6 주 후 총 4 회 측정하 였다. 모든 측정에 있어 검사 4시간 전 음식물 섭취와 검 사 48 시간 전 음주 그리고 검사 12 시간 전에 운동을 실시 하지 못하도록 통제하였으며, 검사 30 분 전에는 반드시 배뇨를 하도록 하였다.

\section{3) 자료 기록 및 수집}

치료 개시, 치료 2주 후, 4주 후, 6 주 후 총 4 회에 걸쳐 이루어진 모든 연구대상자에 대한 신체계측 및 신체구성 자료는 신장 자동측정장치와 체성분분석기를 통해 자동 변환된 자료에서 추출하여 수집하였으며, 연구 대상자의 연령, 성별, 성명, 폐경 유무, 일상생활 신체활동, 흡연, 약 물복용, 질환 및 수술 경험 등을 포함하는 환자의 신상정 보, 생활습관 및 과거력 등의 치료 개시 전 문진-설문지 자료는 수기로 기입하여 작성하였다.

\section{4) 자료 처리}

모든 자료는 SPSS for Window ver. 22.0 (IBM Co., Armonk, $\mathrm{NY}, \mathrm{USA}$ )을 이용하여 자료 처리하였다.

(1) 폐경 전 - 후 집단 간 신체적 특성에 대한 동질성 검
증을 위하여 independent T-test를 실시하였다.

(2) 치료 $0 \sim 2$ 주, 치료 2 4주, 치료 4 6주 총 3 회에 나타 난 모든 자료는 평균과 표준편차를 산출하였다.

(3) 연구의 설계는 스플릿플롯설계(split-plot design)로 $2 \times 3$ (집단×측정시점)의 반복측정에 의한 이원반복 분산분석(two-way repeated measures ANOVA)을 사 용하였다. 폐경 전 - 후 두 집단 간 구분은 개체간 요인(between-subjects factor)으로, 총 3 회에 이루어진 측정시점 변인은 개체내요인(within-subject factor) 으로 설계하였다.

(4) 종속변인은 체중, 체지방률, 골격근량 및 안정시대 사율로 모든 종속변인의 추이변화를 알아보기 위해 구형성(sphericity)을 고려한 Greenhouse-Geisser의 보정된 유의확률을 이용하였으며, 구체적인 변화를 확인하기 위해서는 사후검증(Bonferroni method)을 실시하였다.

(5) 모든 변인은 유의도 $\alpha=0.05$ 수준에서 검증하였다.

\section{결과}

본 연구는 폐경 전 - 후 여성을 대상으로 GB-001이 체 중, 체지방률, 골격근량 및 안정시대사율에 미치는 효과 를 후향적으로 비교 - 분석하여 다음과 같은 연구결과를 도출하였다.

\section{1. 대상자들의 일반적 특성}

최종적으로 선정된 대상자들에서 연령, 신장, 체중 및 신체 질량지수를 측정하였다. 폐경 전 여성 그룹(Pr-MOG, $n=34)$ 에 서 평균 연령은 $48.82 \pm 2.30$ 세, 평균 신장은 $158.24 \pm 6.39 \mathrm{~cm}$, 평균 체중은 $68.06 \pm 7.83 \mathrm{~kg}$, 평균 신체질량지수는 $27.23 \pm 3.20$ $\mathrm{kg} / \mathrm{m}^{2}$ 이었다. 폐경 후 여성 그룹(Po-MOG, $\left.\mathrm{n}=23\right)$ 에서 평균

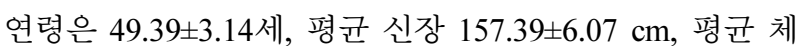
중 $65.65 \pm 6.96 \mathrm{~kg}$, 평균 신체질량지수는 $26.56 \pm 2.99 \mathrm{~kg} / \mathrm{m}^{2}$ 으로 폐경 전 - 후 집단의 동질성 검증을 위해 수행한 independent T-test 결과 두 집단 간 유의한 차이가 없었다 (Table 2).

\section{2. 신체구성}

\section{1) 체중 변화율의 차이}

폐경 유무와 GB-001 비만치료가 체중 변화에 미치는 
Table 2. Physical Characteristics and Independent T-test Results of Pr-MOG and Po-MOG

\begin{tabular}{|c|c|c|c|c|c|c|c|}
\hline \multirow[t]{2}{*}{ Variable } & \multirow{2}{*}{$\begin{array}{c}\mathrm{Pr}-\mathrm{MOG} \\
(\mathrm{n}=34)\end{array}$} & \multirow{2}{*}{$\begin{array}{c}\text { Po-MOG } \\
(n=23)\end{array}$} & \multicolumn{2}{|c|}{$\begin{array}{c}\text { Levene's test for equality } \\
\text { of variances }\end{array}$} & \multirow[t]{2}{*}{$\mathrm{t}$} & \multirow{2}{*}{$d f$} & \multirow{2}{*}{$\mathrm{P}$-value } \\
\hline & & & $\mathrm{F}$ & P-value & & & \\
\hline Age (yr) & $48.82 \pm 2.30$ & $49.39 \pm 3.14$ & 6.440 & 0.014 & -0.742 & 37.562 & 0.463 \\
\hline Height $(\mathrm{cm})$ & $158.24 \pm 6.39$ & $157.39 \pm 6.07$ & 0.112 & 0.740 & 0.502 & 55 & 0.618 \\
\hline Weight (kg) & $68.06 \pm 7.83$ & $65.65 \pm 6.96$ & 0.533 & 0.468 & 1.192 & 55 & 0.238 \\
\hline BMI $\left(\mathrm{kg} / \mathrm{m}^{2}\right)$ & $27.23 \pm 3.20$ & $26.56 \pm 2.99$ & 0.160 & 0.691 & 0.795 & 55 & 0.430 \\
\hline
\end{tabular}

Values are presented as mean \pm standard deviation.

Pr-MOG: pre-menopausal obesity group, Po-MOG: post-menopausal obesity group, df: degree of freedom, BMI: body mass index.

Table 3. The Difference of Weight Change Rate

\begin{tabular}{|c|c|c|c|c|c|c|}
\hline \multirow{2}{*}{ Group } & \multicolumn{3}{|c|}{ Measurement period } & \multirow{2}{*}{$\mathrm{F}$} & \multirow{2}{*}{ P-value } & \multirow{2}{*}{ Post-hoc } \\
\hline & $0-2$ weeks $^{a}$ & 2-4 weeks $^{b}$ & 4-6 weeks ${ }^{c}$ & & & \\
\hline $\mathrm{Pr}-\mathrm{MOG}^{\mathrm{A}}$ & $-4.36 \pm 1.99$ & $-2.32 \pm 1.02$ & $-2.49 \pm 1.27$ & 19.797 & 0.000 & $a<b=c$ \\
\hline Po-MOG ${ }^{B}$ & $-3.62 \pm 1.19$ & $-1.31 \pm 1.28$ & $-0.51 \pm 0.89$ & 46.734 & 0.000 & $a<b<c$ \\
\hline $\mathrm{F}$ & & 29.950 & & \multirow{3}{*}{\multicolumn{3}{|c|}{$\begin{array}{l}\text { Interaction effect } \\
F=3.470, \quad P=0.035\end{array}$}} \\
\hline $\mathrm{P}$-value & & 0.000 & & & & \\
\hline Post-hoc & NS & $A<B$ & $A<B$ & & & \\
\hline
\end{tabular}

Values are presented as mean \pm standard deviation, Unit $=\%$.

Pr-MOG: pre-menopausal obesity group, Po-MOG: post-menopausal obesity group, NS: none-significance.

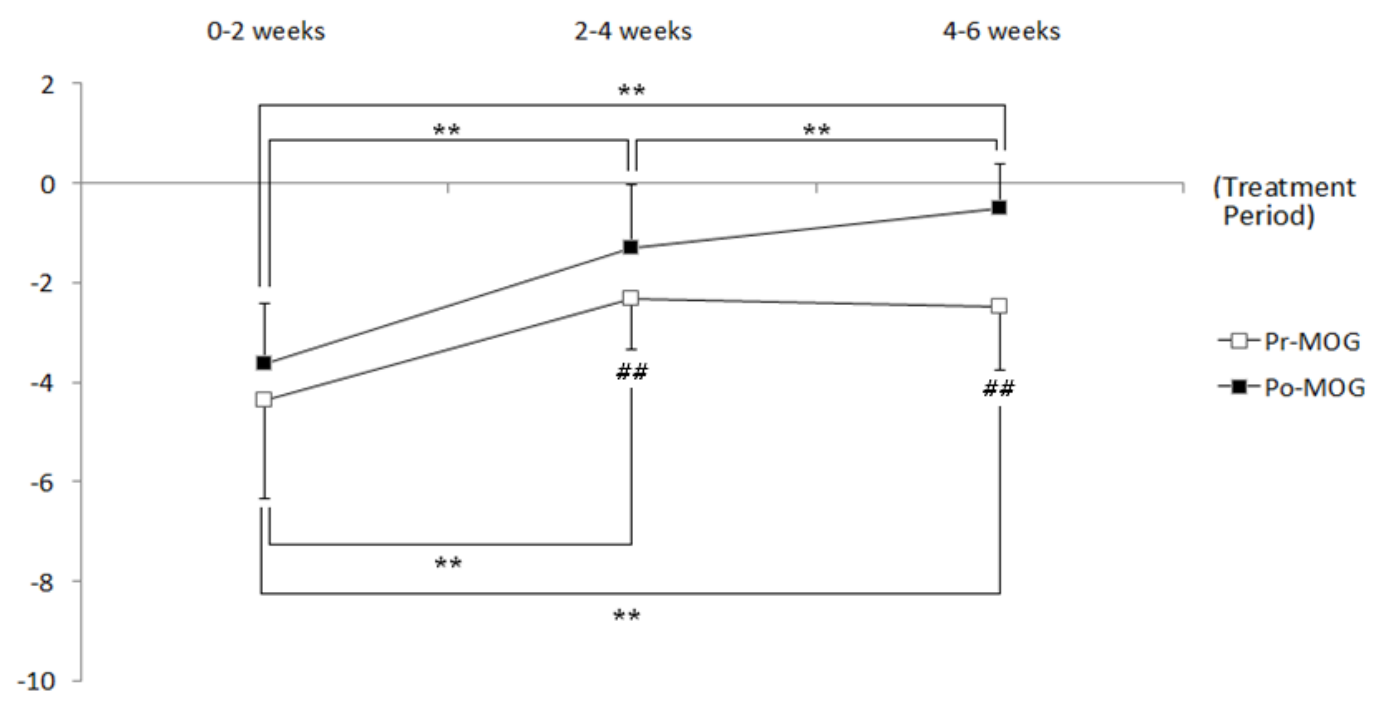

$(\%)$

Fig. 1. The difference of weight change rate. ${ }^{*}$ The difference of the weight change rate by the measurement periods of the Pr-MOG and Po-MOG. Pr-MOG: pre-menopausal obesity group, Po-MOG: post-menopausal obesity group. \#The difference of between weight change rate of $\mathrm{Pr}-\mathrm{MOG}$ and $\mathrm{Po}-\mathrm{MOG}$ by measurement period. ${ }^{*} \mathrm{P}<.01$, \#\#P<.01.

영향을 확인하기 위해 교호작용의 효과 $(\mathrm{F}=3.470, \mathrm{P}=0.035)$

가 나타남에 따라 폐경 유무와 측정시점에 대한 효과검증 과 사후분석을 실시하였다(Table 3, Fig. 1).

폐경 전·후 집단에 대한 측정 시점 간 체중 감소율은
치료 0 2주에 각각 $4.36 \pm 1.99 \%$ 와 $3.62 \pm 1.19 \%$ 로 두 집단 간 유의한 차이가 없었으나, 치료 2 4주에 각각 $2.32 \pm 1.02 \%$ 와 $1.31 \pm 1.28 \%$, 치료 4 6주에 각각 $2.49 \pm 1.27 \%$ 와 $0.51 \pm 0.89 \%$ 로 폐경 후 비만 집단의 체중 감소율이 유의하게 낮은 것 


\section{으로 나타났다 $(\mathrm{F}=29.950, \mathrm{P}=0.000)$.}

측정시점에 따른 폐경 전 집단의 체중 변화는 치료 $0 \sim 2$ 주 $4.36 \pm 1.99 \%$ 감소하였고, 치료 2 4주 $2.32 \pm 1.02 \%$ 감소 하였으며, 치료 4 6주 $2.49 \pm 1.27 \%$ 감소하였다. 이와 같은 측정 시점 간 폐경 전 집단의 체중 감소율은 치료 2 4주 와 치료 4 6주가 치료 0 2주보다 유의하게 낮았으며, 치 료 2 4주와 치료 4 6주 사이에 감소율은 유의한 차이가 없는 것으로 나타났다 $(\mathrm{F}=19.797, \mathrm{P}=0.000)$.

측정시점에 따른 폐경 후 집단의 체중 변화는 치료 0 2 주 $3.62 \pm 1.19 \%$ 감소하였고, 치료 2 4주 $1.31 \pm 1.28 \%$ 감소 하였으며, 치료 4 6주 $0.51 \pm 0.89 \%$ 감소하였다. 이와 같은 측정 시점 간 폐경 후 집단의 체중 감소율은 치료 2 4주 와 치료 4 6주가 치료 0 2주보다 유의하게 낮았으며, 치
료 4 6주가 치료 2 4주보다 유의하게 낮은 것으로 나타 났다 $(\mathrm{F}=46.734, \mathrm{P}=0.000)$.

\section{2) 체지방률 변화율의 차이}

폐경 유무와 GB-001 비만치료가 체지방률 변화에 미 치는 영향을 확인하기 위해 교호작용의 효과 $(\mathrm{F}=0.461, \mathrm{P}=$ $0.632)$ 가 없어 폐경 유무 $(\mathrm{F}=2.774, \mathrm{P}=0.101)$ 와 측정시점 $(\mathrm{F}=$ $6.834, \mathrm{P}=0.002)$ 에 대한 주효과 분석을 실시하였다(Table 4, Fig. 2).

폐경 전 · 후 집단에 대한 측정 시점 간 체지방률의 감 소율은 치료 0 2주에 각각 $5.46 \pm 5.86 \%$ 와 $5.24 \pm 4.44 \%$, 치 료 2 4주에 각각 $3.75 \pm 3.74 \%$ 와 $2.08 \pm 3.17 \%$, 치료 4 6주 에 각각 $3.45 \pm 3.66 \%$ 와 $1.99 \pm 3.08 \%$ 로 두 집단 간 유의한

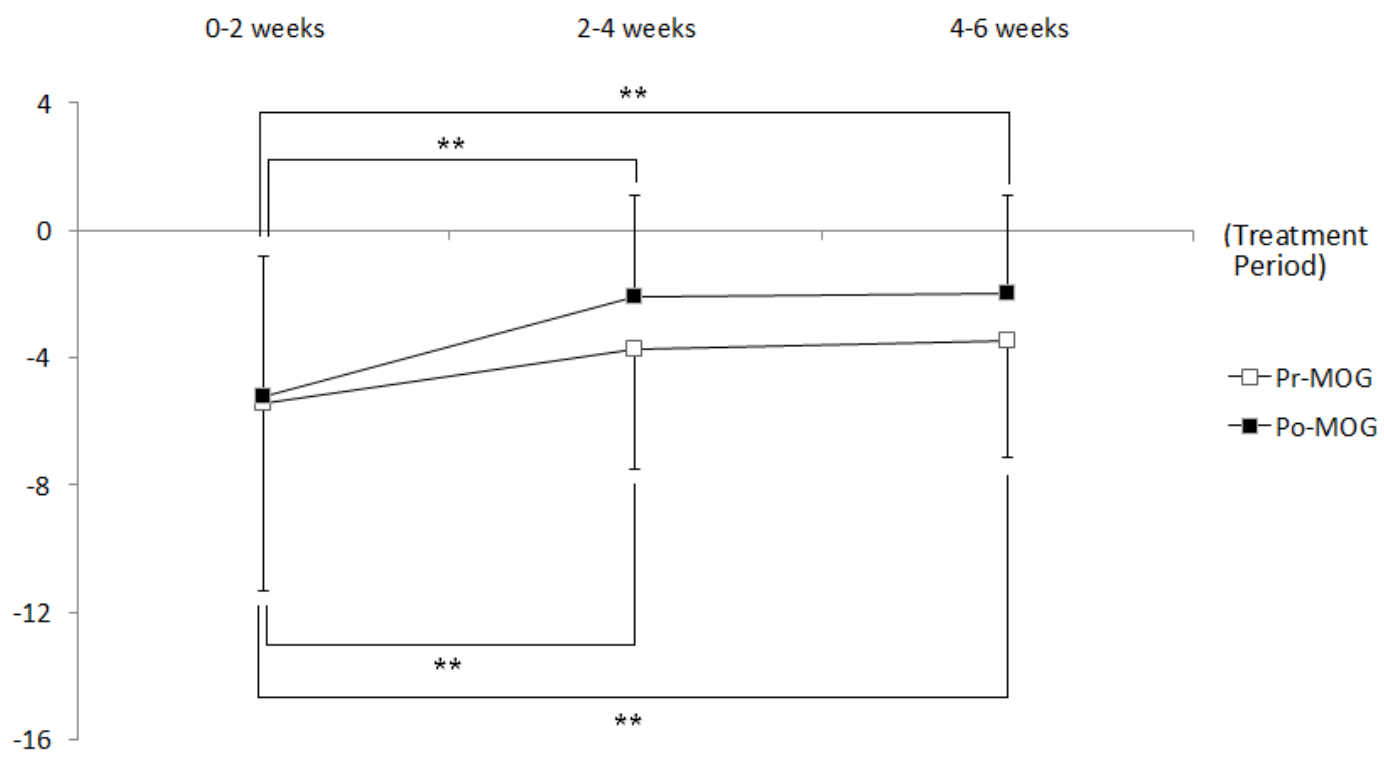

$(\%)$

Fig. 2. The difference of change rate in body fat rate. Pr-MOG: pre-menopausal obesity group, Po-MOG: post-menopausal obesity group. ${ }^{*}$ The difference of the body fat rate change rate by the measurement periods of the Pr-MOG and Po-MOG. ${ }^{* *} P<.01$.

Table 4. The Difference of Change Rate in Body Fat Rate

\begin{tabular}{|c|c|c|c|c|c|c|}
\hline \multirow{2}{*}{ Group } & \multicolumn{3}{|c|}{ Measurement period } & \multirow{2}{*}{$\mathrm{F}$} & \multirow{2}{*}{ P-value } & \multirow{2}{*}{ Post-hoc } \\
\hline & $0-2$ weeks $^{a}$ & 2-4 weeks $^{b}$ & $4-6$ weeks $^{c}$ & & & \\
\hline $\mathrm{Pr}-\mathrm{MOG}^{\mathrm{A}}$ & $-5.46 \pm 5.86$ & $-3.75 \pm 3.74$ & $-3.45 \pm 3.66$ & \multirow{2}{*}{6.834} & \multirow{2}{*}{0.002} & \multirow{2}{*}{$a<b=c$} \\
\hline Po-MOG ${ }^{B}$ & $-5.24 \pm 4.44$ & $-2.08 \pm 3.17$ & $-1.99 \pm 3.08$ & & & \\
\hline $\mathrm{F}$ & \multicolumn{3}{|c|}{2.774} & \multirow{2}{*}{\multicolumn{3}{|c|}{$\begin{array}{l}\text { Interaction effect } \\
F=0.461, P=0.632\end{array}$}} \\
\hline P-value & \multicolumn{3}{|c|}{0.101} & & & \\
\hline Post-hoc & \multicolumn{3}{|c|}{ NS } & & & \\
\hline
\end{tabular}

Values are presented as mean \pm standard deviation, Unit $=\%$.

Pr-MOG: pre-menopausal obesity group, Po-MOG: post-menopausal obesity group, NS: none-significance. 
차이가 없었다.

측정시점에 따른 폐경 전 집단의 체지방률 변화는 치

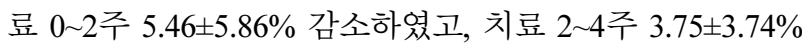
감소하였으며, 치료 4 6주 $3.45 \pm 3.66 \%$ 감소하였다.

측정시점에 따른 폐경 후 집단의 체지방률 변화는 치 료 0 2주 5.24 $\pm .44 \%$ 감소하였고, 치료 2 4주 $2.08 \pm 3.17 \%$ 감소하였으며, 치료 4 6주 $1.99 \pm 3.08 \%$ 감소하였다. 이와 같은 측정 시점 간 폐경 전·후 두 집단의 체지방률의 감 소율은 치료 2 4주, 치료 4 6주가 치료 0 2주보다 유의하 게 낮았으며, 치료 2 4주와 치료 4 6주 사이에 감소율은 유의한 차이가 없는 것으로 나타났다.

\section{3) 골격근량 변화율의 차이}

폐경 유무와 GB-001 비만치료가 골격근량 변화에 미치 는 영향을 확인하기 위해 교호작용의 효과 $(\mathrm{F}=5.119, \mathrm{P}=0.028)$ 가 나타남에 따라 폐경 유무와 측정시점에 대한 효과검증 과 사후분석을 실시하였다(Table 5, Fig. 3).

폐경 전 - 후 집단에 대한 측정 시점 간 골격근량 감소 율은 치료 $0 \sim 2$ 주에 각각 $2.66 \pm 1.51 \%$ 와 $3.47 \pm 4.40 \%$, 치료 $2 \sim 4$ 주에 각각 $1.59 \pm 4.19 \%$ 와 $3.63 \pm 3.88 \%$ 로 두 집단 간 유 의한 차이가 없었으나, 치료 $4 \sim 6$ 주에 각각 $0.03 \pm 3.19 \%$ 와 $3.35 \pm 2.22 \%$ 로 폐경 후 비만 집단의 골격근량 감소율이 유 의하게 높은 것으로 나타났다 $(\mathrm{F}=23.932, \mathrm{P}=0.000)$.

측정시점에 따른 폐경 전 집단의 골격근량 변화는 치 료 0 2주 2.66 $\pm 1.51 \%$ 감소하였고, 치료 2 4주 $1.59 \pm 4.19 \%$

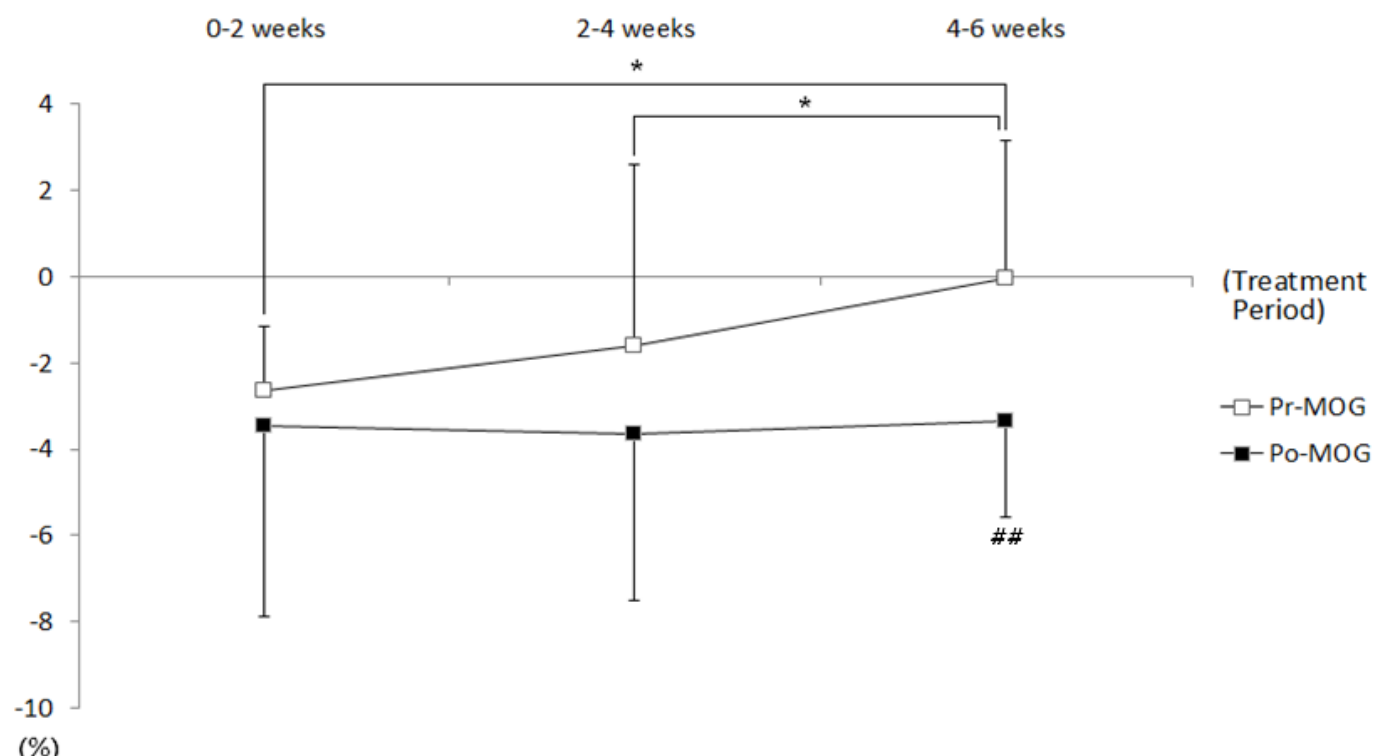

Fig. 3. The difference of change rate in skeletal muscle mass. Pr-MOG: pre-menopausal obesity group, Po-MOG: post-menopausal obesity group. *The difference of the skeletal muscle mass change rate by the measurement periods of the Pr-MOG and Po-MOG, \# The difference of between skeletal muscle mass change rate of Pr-MOG and Po-MOG by measurement period. *P<.05, \#\#P<.01.

Table 5. The Difference of Change Rate in Skeletal Muscle Mass

\begin{tabular}{|c|c|c|c|c|c|c|}
\hline \multirow{2}{*}{ Group } & \multicolumn{3}{|c|}{ Measurement period } & \multirow{2}{*}{$\mathrm{F}$} & \multirow{2}{*}{ P-value } & \multirow{2}{*}{ Post-hoc } \\
\hline & 0-2 weeks ${ }^{a}$ & 2-4 weeks $^{b}$ & $4-6$ weeks $^{c}$ & & & \\
\hline $\mathrm{Pr}-\mathrm{MOG}^{\mathrm{A}}$ & $-2.66 \pm 1.51$ & $-1.59 \pm 4.19$ & $-0.03 \pm 3.19$ & 6.208 & 0.003 & $a=b<c$ \\
\hline Po-MOG ${ }^{B}$ & $-3.47 \pm 4.40$ & $-3.63 \pm 3.88$ & $-3.35 \pm 2.22$ & 0.033 & 0.967 & NS \\
\hline $\mathrm{F}$ & \multicolumn{3}{|c|}{23.932} & \multirow{2}{*}{\multicolumn{3}{|c|}{$\begin{array}{l}\text { Interaction effect } \\
F=5.119, \quad P=0.028\end{array}$}} \\
\hline$P$-value & \multicolumn{3}{|c|}{0.000} & & & \\
\hline Post-hoc & NS & NS & $A>B$ & & & \\
\hline
\end{tabular}

Values are presented as mean \pm standard deviation, Unit $=\%$.

Pr-MOG: pre-menopausal obesity group, Po-MOG: post-menopausal obesity group, NS: none-significance. 
감소하였으며, 치료 4 6주 $0.03 \pm 3.19 \%$ 감소하였다. 이와 같은 측정 시점 간 폐경 전 집단의 골격근량 감소율은 치 료 0 2주와 치료 2 4주가 치료 4 6주보다 유의하게 높은 것으로 나타났다 $(\mathrm{F}=6.208, \mathrm{P}=0.003)$.

측정시점에 따른 폐경 후 집단의 골격근량 변화는 치

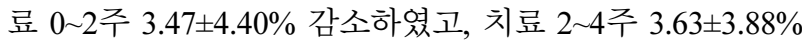
감소하였으며, 치료 4 6주는 $3.35 \pm 2.22 \%$ 감소하였다. 이 와 같은 측정 시점 간 폐경 후 집단의 골격근량 감소율은 치료 0 2주, 치료 2 4주, 치료 4 6주 사이에 유의한 차이 가 없는 것으로 나타났다 $(\mathrm{F}=0.033, \mathrm{P}=0.967)$.

\section{4) 안정시대사율 변화율의 차이}

폐경 유무와 GB-001 비만치료가 안정시대사율 변화에
미치는 영향을 확인하기 위해 교호작용의 효과 $(\mathrm{F}=0.262$, $\mathrm{P}=0.611)$ 가 없어 폐경 유무 $(\mathrm{F}=0.012, \mathrm{P}=0.913)$ 와 측정시점 $(\mathrm{F}=4.002, \mathrm{P}=0.021)$ 에 대한 주효과 분석을 실시하였다(Table 6, Fig. 4).

폐경 전 - 후 집단에 대한 측정 시점 간 안정시대사율 의 변화는 치료 0 2주에 각각 $1.29 \pm 3.54 \%$ 와 $1.52 \pm 2.67 \%$, 치료 2 4주에 각각 $0.45 \pm 3.35 \%$ 와 $0.79 \pm 3.40 \%$ 감소하고, 치료 4 6주에 각각 $0.41 \pm 2.63 \%$ 와 $0.89 \pm 4.13 \%$ 증가하였으 나 두 집단 간 유의한 차이가 없었다.

측정시점에 따른 폐경 전 집단의 안정시대사율 변화는 치료 0 2주 $1.29 \pm 3.54 \%$ 감소하였고, 치료 2 4주 $0.45 \pm 3.35 \%$ 감소하였으며, 치료 4 6주 $0.41 \pm 2.63 \%$ 증가하였다.

측정시점에 따른 폐경 후 집단의 안정시대사율 변화는

0-2 weeks 2-4 weeks 4-6 weeks

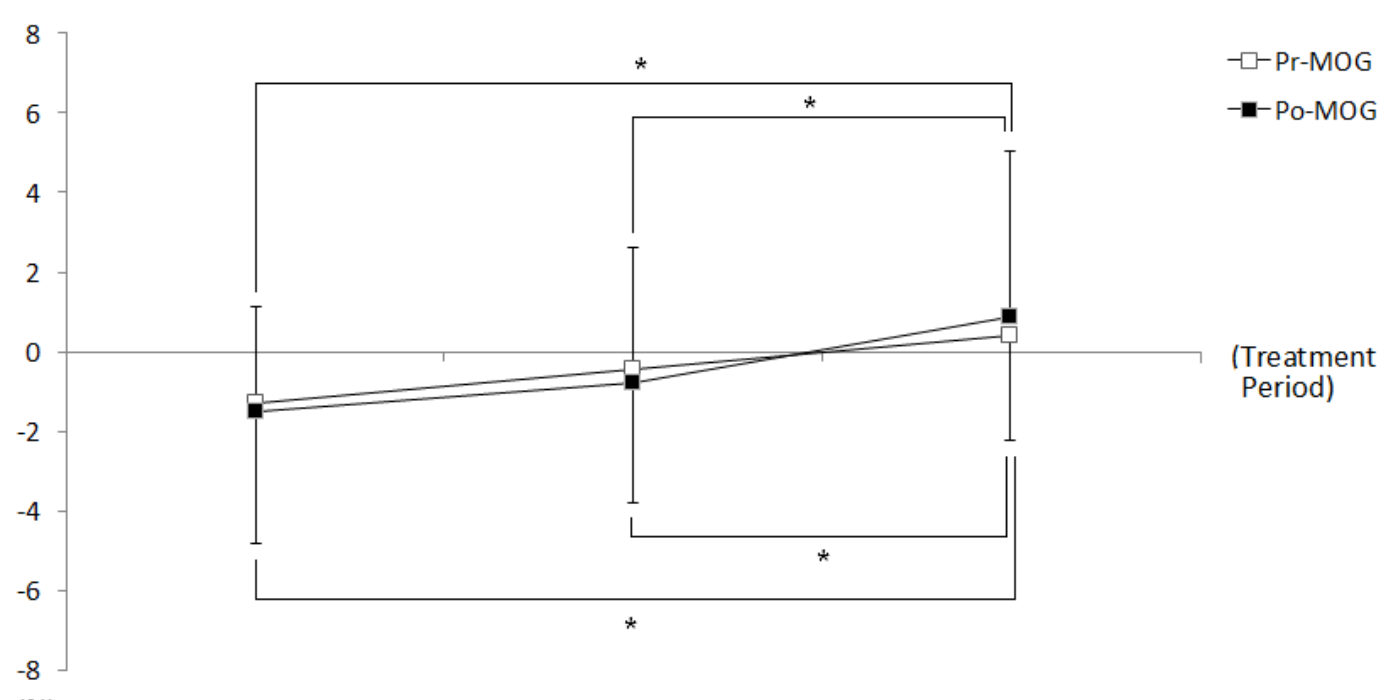

(\%)

Fig. 4. The difference of change rate in basal metabolic rate. Pr-MOG: pre-menopausal obesity group, Po-MOG: post-menopausal obesity group. ${ }^{*}$ The difference of the basal metabolic rate change rate by the measurement periods of the $\operatorname{Pr}-\mathrm{MOG}$ and $\mathrm{Po}-\mathrm{MOG}$. ${ }^{*} \mathrm{P}\langle .05$.

Table 6. The Difference of Change Rate in Basal Metabolic Rate.

\begin{tabular}{lccccc}
\hline \multirow{2}{*}{ Group } & \multicolumn{3}{c}{ Measurement period } & & P-value \\
\cline { 2 - 4 } & $0-2$ weeks $^{\mathrm{a}}$ & $2-4$ weeks $^{\mathrm{b}}$ & $4-6$ weeks $^{\mathrm{c}}$ & & Post-hoc \\
\hline Pr-MOG $^{\mathrm{A}}$ & $-1.29 \pm 3.54$ & $-0.45 \pm 3.35$ & $0.41 \pm 2.63$ & & 0.021 \\
Po-MOG $^{\mathrm{B}}$ & $-1.52 \pm 2.67$ & $-0.79 \pm 3.40$ & $0.89 \pm 4.13$ & & $\mathrm{a}=\mathrm{b}<\mathrm{c}$ \\
F & & 0.012 & & Interaction effect \\
P-value & 0.913 & & $\mathrm{~F}=0.262, \mathrm{P}=0.611$ \\
Post-hoc & $\mathrm{NS}$ & & \\
\hline
\end{tabular}

Values are presented as mean \pm standard deviation, Unit $=\%$.

Pr-MOG: pre-menopausal obesity group, Po-MOG: post-menopausal obesity group, NS: none-significance. 
치료 0 2주 $1.52 \pm 2.67 \%$ 감소하였고, 치료 2 4주 $0.79 \pm 3.40 \%$ 감소하였으며, 치료 4 6주 $0.89 \pm 4.13 \%$ 증가하였다. 이와 같은 측정 시점 간 폐경 전·후 두 집단의 안정시대사율 변화율은 치료 0 2주, 치료 2 4주가 치료 4 6주보다 유의 하게 낮은 것으로 나타났다.

\section{고찰}

본 연구는 하늘체한의원 춘천점에서 비만치료를 위해 활용하고 있는 GB-001을 복용하였을 때 폐경 전·후 중 년여성의 체중, 체지방률, 골격근량 및 안정시대사율의 변화를 살펴본 후향적 연구이다. GB-001은 하늘체한의원 춘천점에서 비만의 중년여성에게 처방하였을 때 경험적으 로 비만치료 및 개선 효과를 보인 한약으로 麻黃, 薏药仁, 當歸, 熟地黃, 龍眼肉, 山藥, 获苓, 澤瀉 각 $10 \mathrm{~g}$ 을 하루 용 량으로, 1일 3회에 나누어 식전 30분에 복용하도록 하였 다. 자가-식이요법과 일상생활 신체활동 등과 같은 생활관 리 교육을 함께 시행하였고 총 6주간의 치료 기간 동안 폐 경 전 - 후 비만 여성의 신체 구성 및 안정시대사율 변화를 관찰하였다. 이때, 중년 여성의 폐경 유무에 따른 GB-001 의 효과를 보다 정확히 분석하고자 연구 결과에 영향을 미칠 수 있는 연령, 성별, 폐경 지속기간, 무월경 경험, 일 상생활 신체활동, 흡연, 약물복용, 질환 및 수술 경험 등 을 포함하는 연구 대상자들의 신상정보, 생활습관 및 과 거력 등을 분석 자료 선정 및 제외 기준으로 하였으며, 이 를 통해 얻어진 결과를 토대로 고찰하고자 한다.

본 연구에서 GB-001을 총 6주간 복용한 여성들에서 전 체적으로 체중 감소, 체지방률 감소의 효과가 나타났으나 골격근량 및 안정시대사율도 함께 감소하는 결과가 나타 났다. 폐경 전 - 후 두 집단에서 신체구성 및 안정시대사 율의 변화를 비교한 결과, 폐경 후 여성에서 폐경 전 여성 에 비해 치료 2 6주간 체중 감소율은 낮고, 4 6주간 골격 근량 감소율은 높은 것으로 나타났으며, 체지방률과 안정 시대사율의 변화율에 있어서는 통계적으로 유의한 차이 가 없는 것으로 나타났다.

치료시기별 체중 감소율은 폐경 전 집단에서는 치료 $0 \sim 2$ 주에 $-4.36 \pm 1.99 \%$ 로 가장 큰 감소율을 보이고, 치료 2 4주와 4 6주에는 각각 $-2.32 \pm 1.02 \%,-2.49 \pm 1.27 \%$ 로 유 의한 차이가 없었던 것에 비해 폐경 후 집단에서는 0 2주, 2 4주, 4 6주로 치료 기간이 길어질수록 각각 $-3.62 \pm 1.19 \%$,
$-1.31 \pm 1.28 \%,-0.51 \pm 0.89 \%$ 로 점차 낮은 감소율을 보인 것 으로 나타났다.

치료시기별 골격근량의 변화율은 폐경 전 집단에서 0 2주와 2 4주에 각각 $-2.66 \pm 1.51 \%,-1.59 \pm 4.19 \%$ 였으나 $4 \sim 6$ 주에는 $-0.03 \pm 3.19 \%$ 로 통계적으로 유의하게 낮은 감 소율을 보였다. 반면, 폐경 후 집단에서는 0 2주, 2 4주, $4 \sim 6$ 주 각각 $-3.47 \pm 4.40 \%,-3.63 \pm 3.88 \%,-3.35 \pm 2.22 \%$ 로 지 속적으로 높은 비율로 감소한 것으로 나타났다.

40 60세 연령기를 일컫는 중년 여성은 노화(aging) 현 상에 의해 다양한 신체적 - 생리적 특성 등의 부정적인 변화와 고혈압, 당뇨병, 고지혈증 등의 생활습관병 발병 과 밀접한 관련이 있는 비만의 높은 유병률을 보이며2,33), 50 세 전·후에는 에스트로겐과 프로게스테론의 감소로 월경이 영구히 중단되어 무월경이 12 개월 이상 지속되는 폐경(menopause)을 맞이하게 된다2). 이러한 폐경은 여성 호르몬인 에스트로겐 부족 혹은 결핍에 의해 발 혹은 허 리가 쑤시거나 시림, 피로, 무기력, 신경과민, 시력 저하 및 열성 홍조 등과 같은 공통적인 증상뿐 아니라 ${ }^{3,34)}$, 부정 적인 생리적 - 체력적 변화의 증가로 여러 건강학적 문제 들을 발생시킨다 ${ }^{35}$.

폐경 후 중년 여성에서 건강과 관련하여 가장 대표적으 로 나타나는 체력 변화는 체중 증가, 골격근량 및 제지방 량 감소, 여성 체형을 남성 체형으로 변화시키는 과정인 허리 대 둔부 비율(waist-hip ratio)이 증가하는 것이다 ${ }^{36,37)}$. 이와 같이 중년 여성은 노화 현상과 폐경에 의해 보다 급 격하고 부정적인 생리적 - 체력적 변화와 건강관련 체력 인 신체구성의 변화로 높은 비만 유병률을 보인다 ${ }^{2-4)}$.

한약은 식욕 억제, 에너지 대사율 증가, 지방조직의 에 너지 소비 증가(산소포화도를 높임)에 따른 체지방 분해 가속화 등의 효과를 나타내어 우리나라 한방 병 - 의원에 서 체중 감량과 비만치료를 위하여 높은 빈도로 이용되고 있으며 ${ }^{1419)}$, 한약의 체중 감량 및 비만치료에 대한 효과는 국내·외 여러 연구를 통해 입증되고 있으나, 연령대를 특정하지 않은 연구들이 많고, 폐경 전 또는 폐경 여성을 대상으로 한 연구는 있으나 이 두 그룹에 대한 한약의 비 만치료 효과를 비교한 연구는 전무한 실정이다. 중년 여 성, 특히 폐경 후 여성은 급격한 신체적 변화를 보인다는 점에서 폐경 전 여성과는 비만치료 효과 측면에서 차이가 있을 수 있으며, 이에 따라 폐경 후 여성에게 비만치료 한 약을 처방할 때 추가적으로 고려해야할 요소들이 있을 것 
으로 생각된다.

폐경기에는 에스트로겐 결핍으로 지방 축적이 가속화 되고 근육과 같은 제지방량이 감소하며, 황체기 에너지 소비가 소실되어 안정시대사율이 감소한다 ${ }^{38)}$. 따라서 동 일한 비만치료를 시행했을 때 폐경 전 여성에 비해 폐경 후 여성에서 체중 감소율이 적고, 골격근량의 감소율은 크 게 나타난 것으로 생각된다. 즉, 폐경기 여성의 비만치료 는 폐경기의 에너지 소비와 신체활동 감소로 폐경 전과 비 교하여 대사율이 저하되기 때문에 치료 반응이 더디며 ${ }^{39)}$, 폐경 유무와 더불어 연령의 증가도 고려했을 때 비만에 대해 보다 집중적인 치료가 필요하다.

따라서 폐경 후 비만 여성에게 폐경 전 비만 여성과 동 일한 한약 비만치료를 단일적으로 적용하는 것은 폐경 후 비만 여성의 비만치료를 위한 치료적 중재 방법으로 고려 될 수 있으나, 보다 효과적인 체중 감량과 골격근의 감소 를 예방하기 위해서는 한약의 성분 및 용량을 조절하거나 식이 및 운동 등 보다 적극적인 생활습관 교정이 필요할 수 있다.

본 연구의 결과를 통해 중년의 비만 여성에게 GB-001 을 이용한 비만치료는 폐경의 유무와 관계없이 체중 감 소, 체지방률 감소의 효과가 있어 효과적인 체중 감량 및 비만치료를 위한 치료적 중재 방법으로 활용될 수 있다고 판단된다. 다만, 골격근량 및 안정시대사율의 감소가 동 반될 수 있으므로 이에 대한 운동량 증가 또는 생활습관 교정이 반드시 필요할 것으로 생각된다. 더욱이, 노화와 폐경의 영향을 동시에 받는 폐경 후 비만 여성에서는 이 러한 요소에 대해 더 많은 관심과 노력이 필요하며, 이 뿐 만 아니라 호르몬 영향으로 유발되는 복부지방, 내장지방 의 축적 및 골밀도 감소 등에 대해서도 함께 고려해야 할 것이다.

본 연구의 결과는 6 주라는 단기간에 동일한 성분 및 용 량의 한약을 적용한 연구 자료를 분석하였고 GB-001을 사 용하지 않는 대조군 없이 후향적 연구로 진행되었다는 한 계점이 있으므로, 향후 폐경 후 비만 여성에 대한 한약 효 능을 보다 명확하게 확인하기 위해서는 GB-001을 사용하 지 않는 대조군뿐 아니라 다양한 용량 및 성분의 GB-001 을 장기간 적용하는 후속 연구가 필요할 것으로 생각된다.
결론

본 연구는 중년의 비만 여성을 대상으로 비만치료 한 약인 H 감비탕(GB-001)을 복용하였을 때 체중, 체지방률, 골격근량 및 안정시대사율의 변화를 폐경 전·후 두 집 단으로 분류하여 후향적으로 비교 - 분석하여 다음과 같 은 결론을 얻었다.

첫째, 폐경 전·후 비만 여성에게 GB-001을 단일적으 로 이용하는 비만치료는 두 집단 모두에서 유의한 체중 및 체지방률의 감소 효과가 있었으나, 골격근량과 안정시 대사율의 감소가 동반되는 것으로 나타났다.

둘째, 폐경 전·후 두 집단의 체중 감소율은 치료 0 2 주까지 유의한 차이가 없었으나, 치료 2-6주에 폐경 후 집 단이 폐경 전 집단에 비해 유의하게 낮았다. 폐경 전 집단 에서는 치료 2 4주와 4 6주 동안 체중 감소율의 유의한 차이가 없던 것에 비해 폐경 후 집단에서는 치료 0 2주, 2 4주, 4 6주로 치료 기간이 길어질수록 체중 감소율이 유의하게 낮아졌다.

셋째, 폐경 전·후 두 집단의 골격근량 감소율은 치료 $0 \sim 4$ 주까지 유의한 차이가 없었으나, 치료 4 6주에 폐경 후 집단이 폐경 전 집단에 비해 유의하게 높았다. 폐경 전 집단에서는 치료 $0 \sim 4$ 주에 비해 4 6주에 유의하게 낮은 골격근량 감소율을 보인 것에 비해, 폐경 후 집단에서는 치료 0 2주, 2 4주, 4 6주까지 골격근량 감소율에 유의한 차이가 없었다.

넷째, 폐경 전·후 두 집단의 체지방률과 안정시대사 율의 변화율은 전체 치료기간 동안 통계적으로 유의한 차 이가 없었다.

\section{References}

1. Park YJ, Sim MJ, Kim HJ, Jeon NM, Kim HY, Lee ES, et al. Maternity \& women's health nursing. 4th ed. Seoul : Hyunmoonsa. 2017 : 241-4.

2. Huh JY, An HJ. The effects of yoga performance on mental health in menopause women. The Korea Journal of Sports Science. 2007 ; 16(2) : 361-71.

3. The Compilation Committee of Korea Society of Menopause. Menopause Health. Paju : Koonja Publishing. 2012. 
4. Nelson HD. Menopause. Lancet. 2008 ; 371(9614) : 760-70.

5. Gong KM, Kim KJ. Comparison of association of exercise participation with abdominal fat area, insulin resistance, and blood lipid profiles between pre-menopausal and post-menopausal women. The Korean Journal of Growth and Development. 2007 ; 15(1) : 9-17.

6. Hagey AR, Warren MP. Role of exercise and nutrition in menopause. Clinical Obstetrics and Gynecology. 2008 ; 51(3) : 627-41.

7. Park YJ, Koo BS, Kang HC, Chun SH, Yoon JW. The menopausal age and climacteric symptoms, and the related factors of Korean women. Korean J Women Health Nurs. 2001 ; 7(4) : 473-85.

8. American College of Sports Medicine. Guidelines for exercise testing and prescription. 7th ed. Philadelphia : Lippincott Williams \& Wilkins. 2005.

9. Monzillo L, Hamdy O. Evaluation of insulin sensitivity in clinical practice and in research settings. Nutrition Reviews. 2003 ; 61 : 397-412.

10. Choi SH. Acupuncture for obesity: a systematic review and meta-analysis. International Journal of Obesity. $2009 ; 33: 183-96$.

11. Jung SK. Effect of Taeyeumjoweetang and electroacupuncture combined therapy on obesuty. J Korea Orein Assoc Stud Obes. 2003 ; 3(1) : 61-7.

12. Hwang DS. The efficacy of low frequency electroacupuncture therapy for weight loss in obese Korean women. The Journal of Oriental Obstetrics \& Gynecology. $2009 ; 22(2): 140-50$.

13. Hyeon C, Seo GS, Shin WY. The retrospective analysis of obesity and overweight female patients with clinical treatment including herbal medicine. The Journal of Society of Korea Medicine Obstetrics and Gynecology. $2016 ; 29(3): 35-46$.

14. Jang IS, Yang CS, Hwang EH. The need for clinical practice guidelines in usage of Mahuang in weight loss. Journal of Society of Korean Medicine for Obesity Research. 2007 ; 7(1) : 23-9.

15. Song YK, Lim HH. Clinical application of Ma Huang in the obesity treatment. Journal of Society of Korean Medicine for Obesity Research. 2007 ; 7(1) : 1-7.

16. Song MY, Kim HJ, Lee MJ. The safety guidelines for use of Ma-huang in obesity treatment. Journal of Society of Korean Medicine for Obesity Research. 2006 ; 6(2) : 17-27.

17. Kim HJ, Han CH, Lee EJ, Song YK, Shin BC, Kim YK. A clinical practice guideline for Ma-huang, ephedra sinica prescription in obesity. Journal of Society of Korean Medicine for Obesity Research. 2007 ; 7(2) : 27-37.

18. Greenway FL, DE Jonge L, Blanchard D, Frisard M, Smith SR. Effect of dietary herbal supplement containing caffeine and ephedra on weight, metabolic rate, and body composition. Obese Res. 2004 ; 12(7) : 1152-7.

19. Hwang MJ, Shin HD, Song MY. Literature review of herbal medicines on treatment of obesity since 2000 mainly about ephedra herba. Journal of Society of Korean Medicine for Obesity Research. 2007 ; 7(1) : 39-54.

20. Shekelle P, Hardy ML, Morton SC, Maglione M, Suttorp M, Roth E, et al. Ephedra and ephedrine for weight loss and athletic performance enhancement: Clinical efficacy and side effects. Evid Rep Technol Assess. 2003 ; 76 : 1-4.

21. Gruenwald J, Brender T, Jaenicke C. PDR for herbal medicines. 3rd ed. Whippany : Physicians Desk Reference. 2004 : 531-9.

22. Mills S, Bone K. The essential guide to herbal safety. London : Churchill Livingstone. 2005 : 380-3.

23. Yeo JJ, Hyung LC, Yang CS, Jeong SI, Seo ES, Jang JS. Effects of Mahuang for weight loss in healthy adults: a double-blind, controlled, randomized, clinical trial. The Society of Korea Medicine. 2007 ; 28(1) : 63-71

24. Kang MH. Effect of ephedra on the anxiety according to Sasang constitution classification. Doctoral Thesis. Wanju : Woosuk University. 2009.

25. Jang IS, Yang CS, Lee SD, Han CH. A review of herbal medicinal products associated with toxic events in Korea. Journal of Korean Medicine. 2007 ; 28(1) : 1-10.

26. Jo SH. The effects of Gamchomahwang-tang extract according to the ratio of 2 compounds on the ovalbumin-induced allergic asthma in mice. Master's Thesis. Iksan : Wonkwang University. 2013.

27. Song MK. The effects of Ephedrae Herba on obese 
type 2 diabetes mouse model induced by high fat, high carbonate diet. Master's Thesis. Seoul : Kyung Hee University. 2009.

28. Lee TH. Adverse effects of Mahuang according to Sasang constitution classification in healthy adults: a double-blind randomized controlled trial. Doctoral Thesis. Wanju : Woosuk University. 2006.

29. Li CH. Short-term effects of Mahuang on state-trait anxiety according to Sasang constitution classification: a double-blind randomized controlled trial. Master's Thesis. Wanju : Woosuk University. 2007.

30. Ryu SM, Jeong SH, Lee JS, Kim SS, Shin HD. The effect of very low calorie diet and Chegamuiyiin-tang on bone mineral density. J Korean Med Obes Res. 2005 ; $5: 87-95$.

31. Kim SJ, Kim HJ, Ko BP, Kim HD, Kim JA, Park JM, et al. Effect of Ephedra Sinica and Evodia Rutaecarpa on resting metabolic rate in obese Prem enopausal women during low-calorie diet : a randomized controlled clinical trial. J Korean Med Obes Res. 2004 ; 4 : 45-54.

32. Nam EY. The systematic review on clinical studies of traditional Korean medicine treatment for obesity in menopausal women. J Korean Med Obes Res. 2019 ;
19(1) : 56-67.

33. Park HR. The research regarding the awareness and practice of weight and skin care of middle-aged women. Master's Thesis. Seoul : Kookmin University. 2003.

34. North America Menopause Society. Treatment of menopause-associated vasomotor symptoms; position statement of The North America Menopause Society. Menopause. 2004 ; 11(1) : 11-33.

35. Choi JH, Yang JH. Effects of Antioxidant supplementation and exercise frequency to body composition, peroxide value and total antioxidant status in obese women. Journal of Sport and Leisure Studies. 2009 ; 36(2) : 635-42.

36. Poehlman ET, Toth MJ, Gardner AW. Changes in energy balance and body composition at menopause: a controlled longitudinal study. Ann Intern Med. 1995 ; 123(9) : 673-5.

37. Wing RR, Matthews KA, Kuller LH, Meilahn EN, Plantinga PL. Weight gain at the time of menopause. Arch Intern Med. $1991 ; 151$ : 97-102.

38. Kim YS. Management of obesity in postmenopausal women. The Journal of the Korean Medical Association. $2005 ; 48(4): 349-53$.

39. Lovejoy JC. The menopause and obesity. Prim Care. $2003 ; 30(2): 317-25$. 